GLOBAL JOURNAL OF EDUCATIONAL RESEARCH VOL 16, 2017: 101-110

COPYRIGHT@ BACHUDO SCIENCE CO. LTD PRINTED IN NIGERIA. ISSN 1596-6224

\title{
THE ROLE OF TEACHING PRACTICE IN TEACHER EDUCATION PROGRAMMES: DESIGNING FRAMEWORK FOR BEST PRACTICE
}

GENEVIEVE AGLAZOR

(Received 17, July 2017; Revision Accepted 9, August 2017)

\begin{abstract}
The teaching practice exercise is the culminating point where the relationship among the three major players: university supervisor, host teacher, and aspiring teacher interface to determine the quality of experience the aspiring teaching will take away. It becomes the bedrock on which the aspiring teacher once certified and employed builds his/her professional identity. It is therefore, necessary that aspiring teachers are paired with competent, knowledgeable and concerned university supervisors to help them assume the full range of duties of a teacher during this hands-on training period. Host teachers have equally vital influence in aspiring teachers' professional growth and development. This paper outlines the rudimentary elements involved in designing teaching practice field exercise for the student teachers.
\end{abstract}

\section{INTRODUCTION}

\section{Philosophy of Teaching Practice}

Good teaching practice is a key influence on student learning - a desired outcome and primary goal of higher educational institutions. Teachers strive to meet the principles of good practice in an effort to provide the best learning experience for their students - Flinders University.

Student Teaching is the most important experience in teacher education programme and is generally based on a country's National Education policy. Teaching practice is a compulsory course for all aspiring student teachers registered in a teacher preparation programme in Nigeria. It is one-semester in duration; usually lasting from the beginning to the end of the First Semester of the final year of students' training. During this period, most programmers focus on:

- Instructional planning

- Instructional technology

- Micro-teaching mentoring (Model Teaching, Assessment, Feedback Reports etc.)
- Studies in teaching methods

- Posting of students to schools where they can practice their major courses of study

The Student Teaching Program at any higher institution is a well-structured programme designed to provide an opportunity to develop and evaluate aspiring teachers' competence in an actual classroom within school settings. In a paper on Global exposure presented at the Research Seminar Series, Aglazor(2011) noted that field-based experiences such as study abroad and student teaching are intended to bridge theory and practice. The teaching practice exercise is the culminating point where the relationship among the three major players: university supervisor, host teacher, and aspiring teacher interface to determine the quality of experience the aspiring teaching will take away. It becomes the bedrock on which the aspiring teacher once certified and employed builds their professional identity. It is therefore, necessary that aspiring teachers are paired with competent, knowledgeable and concerned university supervisors to help them assume the full range of duties of a teacher during this hands-on training

Genevieve Aglazor, Department of Curriculum \& Teaching, University of Calabar, Calabar, Cross River State, Nigeria. 
period. Host teachers have equally vital influence in aspiring teachers' professional growth and development.

A College of Education or University Faculty of Education Teacher Education Programme is informed by its institution's unique vision and mission. For validity, education programmers' must be guided by their institution's vision and philosophical theories. This underscores the reason why programmers must make sure their student teachers understand both the institution and programme's educational philosophy.

\section{COURSE DESCRIPTION}

A course description is a brief statement designed and intended to inform students about the subject matter, content, breadth and practical applicability of the course. It is also used to inform for student enroll and transfer. Students like to know what they are going to learn in a course before they enroll in a course. Also, if a student transfers to another institution, the course description helps them identify transferable and equivalent courses to the new school. Additionally, it is used for institutional accreditation as proof of content covered in the different subject areas.

In the tradition of best practice, all courses are expected to have course descriptions; so does Teaching Practice. It is important that your faculty of education design a course description for your teaching practice programme.

\section{SAMPLE COURSE DESCRIPTION}

This Teaching Practice course (EDU 0000) is based on National Universities Commission and the National Policy on Education mandate for Basic primary and secondary education programmes. The Student Teaching Programme is designed to develop and evaluate student teachers' competence in actual classroom and school settings. The programme is intended to bridge theory and practice by providing opportunity for hands-on learning for Student Teachers. Consequently, participants are given the opportunity to demonstrate clear understanding of best practice in different teaching methods to meet students' learning needs and classroom management skills. Relying on the partnership of competent, knowledgeable and caring cooperating teachers and host schools, Student Teachers assume the full range of duties of a teacher in real classrooms. Based on meaningful mentoring and collaboration among University Supervisors, Cooperating Teachers and the Student Teachers at the end of this field experience participants would demonstrate clear understanding of best practice in students' developmental levels, different teaching methods to meet students' learning needs and classroom management skills.

\section{OBJECTIVES OF TEACHING PRACTICE}

According to National Universities Commission (NUC, 2007) Benchmark and National Commission for Colleges of Education (NCCE, 2015), the following sets of objectives have been established for why teaching practice is a mandatory component of teacher training.

i. To expose student-teachers to real life classroom experiences under the supervision of professional teachers.

ii. To provide the forum for student-teacher to translate educational theories and principles into practice.

iii. To enable student-teachers discover their own strengths and weaknesses in classroom teaching and provide opportunities to enable them address their weaknesses and enrich their strengths.

iv. To familiarize student-teachers with real school environment as their future work place.

v. To provide student-teachers with an opportunity for further acquisition of professional skills, competencies, personal characteristics and experience for full-time teaching after graduation.

vi. To help student-teachers develop a positive attitude towards the teaching profession.

vii. To serve as a means of assessing the quality of training being provided by teacher training institutions.

\section{Teaching Practice Committee}

Teaching Practice Committee is a vital tool to programme managers. Depending on the size of your school, your teaching practice committee serves as an advisory board for decisions and changes that lead to programme improvement. Membership of the teaching practice committee can be by appointment or selection. One objective way to go about it is to 
have a faculty member from every department in the Faculty of Education and other departments whose students participate in teaching practice field experience. So the teaching practice committee should be a balanced representation of the faculty of education. The different roles that can be assigned to committee members include, but not limited to:

Coordinator of $\mathrm{T}$ P/Chair of $\mathrm{T} P$ Committee, Secretary, Members, Social Secretary

Duties of committee members include searching for and securing schools for teaching practice, field supervision and first line respondents in times of crisis at host schools. It is suggested that committee members' contact information be made available to students on teaching practice should they need advice and support at any point during their field experience.
The chart below is only a guide and should be modifies to suit your institution and programme needs.

\section{Teaching Practice Triad}

This triangle is also referred to as

'Student Teaching Triad. Success of teaching practice depends on the collaboration among cooperating teacher, university supervisor and aspiring teacher. The primary goal of this team is to guide the aspiring teacher to successful completion of teaching practice. It is important for the team to have a clear understanding of the programme expectations for teaching practice participants. To function as a team, communication and positive interaction are necessary ingredients needed for clarity of purpose and for collaboratively guiding, mentoring and supporting student teachers.

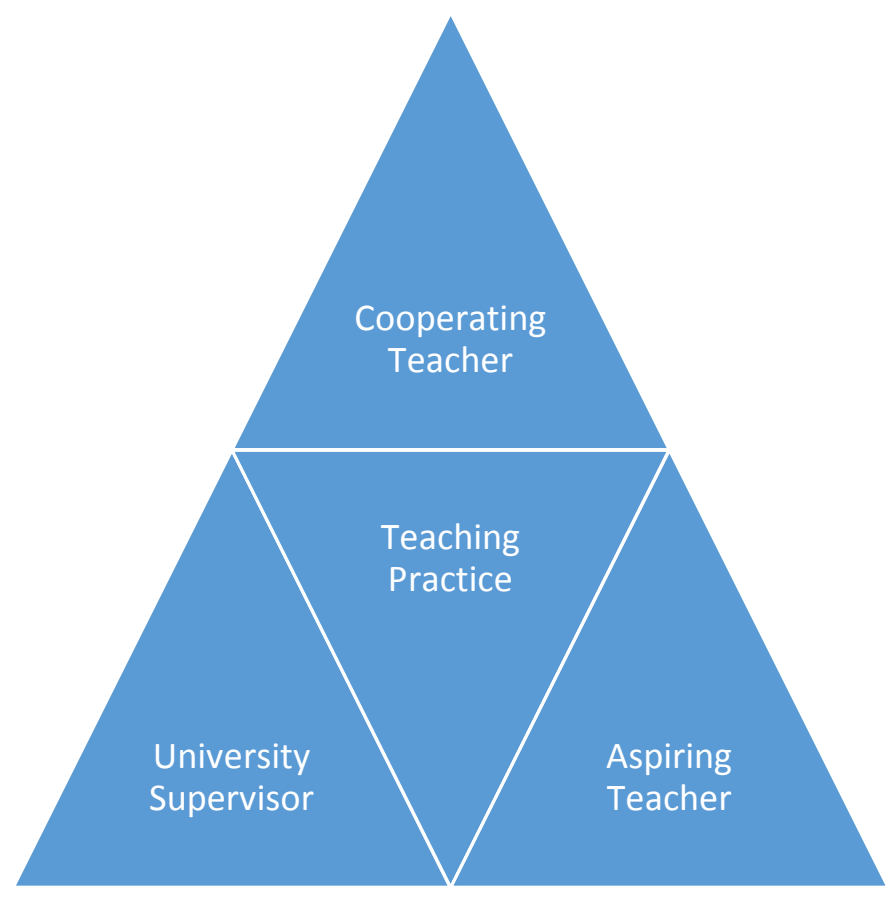

The Aspiring Teacher's field experience is the culminating activity for teacher candidates. Efforts should be made by programme managers to place aspiring teachers at schools and subjects that corresponds with their intended teaching license.
Cooperating Teachers are integral to successful professional teacher training or teacher education programme. They are field mentors due to their experience in the classrooms. They are expected to guide student teachers during their teaching practice in areas of instructional design, classroom management, 
assessment and broader notion of being a teacher.

Different institutions may have established standards that cooperating teachers must meet in order to host their student teachers. For example, cooperating teachers should have a minimum of three years of teaching experience at their current school. This will provide them enough knowledge about the school and the system to guide student teachers. Cooperating teachers should be required to complete a course or seminar in supervision of student teachers. They should also hold some kind of teaching license.

The University Supervisor who is the third prong of the triad should be well acquainted with the professional teacher training or teacher education programme and performance expectations for the student teacher. They are the performance experts charged with evaluating and assessing student teachers during teaching practice. Ideally, supervisors should visit and meet with student teachers at their assigned postings at least three times during the twelveweek field experience to enable the supervisors make informed decisions regarding aspiring teachers' progress and performance in as prospective classroom teachers. The first meeting should be at the beginning of the teaching practice. At this meeting supervisor should set expectations, answer any questions that the student teacher may have. The second meeting should be evaluative in nature; where the supervisor observes the student teacher and provide feedback, set on-going goals and answer any new questions that the student teacher may have. The final meeting should be a conclusive evaluation meeting to determine completion of the field experience and final grade. The supervisors also facilitate the scheduled meetings among cooperating teachers, student teachers and supervisors otherwise known as 'Triad Meetings' to ensure open communication regarding overall programme and successful completion of teacher education requirements for licensure. Triad meetings also provide opportunities for student teachers to discuss in a safe supportive environment and issues that emerge during field experience. Supervisors are also responsible with assigning final grades for completing student teaching.

\section{Primary Goals of Teaching Practice}

The central goal of Student Teaching Programmes is to provide aspiring teachers challenging, relevant and rewarding field experiences to inculcate essential teaching skills and professional growth.

Teaching Practice is an opportunity for aspiring teachers to understand the role and operation of how the business of schooling is done. This field experience provides a challenging yet rewarding experience of working with students in actual classrooms and acquiring professional competence. It is believed that these experiences have the potential to enhance the teachers' acquisition of professional competence. Acquired experiences will include among other things, their ability to assume the various responsibilities of the classroom teacher as shared by Saphier, Haley-Speca \& Gower (2008).

$\checkmark$ Plan and deliver instruction that meets the learning needs of all students regardless of their individual learning styles, developmental and cognitive levels.

$\checkmark$ Organize and manage the classroom environment for maximum academic performance.

$\checkmark$ Manage classroom interactions and student's behavior to create safe, conducive learning atmosphere for student academic success.

$\checkmark$ Work cooperatively and collaboratively with students, parents, and other members of school community for the benefit of students learning.

$\checkmark$ Exercise decision making in identifying and using age, content and grade level appropriate instructional strategies in lesson delivery.

$\checkmark \quad$ Using appropriate assessment tools and methods to determine student learning

$\checkmark$ Use reflective practice to evaluate effectiveness of meeting intended instructional objectives.

$\checkmark$ Create a dynamic classroom environment which fosters positive, effective communication among students, teachers, parents and other members of school community.

$\checkmark$ Demonstrate self-confidence and knowledge of your content and the importance of your curriculum to students' everyday life.

$\checkmark$ Understand the role and operation of the school 
$\checkmark$ Respect and work effectively with students of varying backgrounds and cultures

$\checkmark$ Assume the various responsibilities of the classroom teacher

$\checkmark \quad$ Plan instruction and learning experiences which recognize the individual needs and differences of students

$\checkmark$ Organize and manage the classroom environment to maximize learning

$\checkmark$ Manage classroom interactions and student conduct to create a positive climate for learning

$\checkmark \quad$ Identify and use appropriate instructional techniques, methods, and resources

$\checkmark$ Evaluate learning to determine the extent to which instructional objectives are achieved by students

$\checkmark$ Establish positive and effective communication with students, parents, colleagues, administrators and community members

$\checkmark$ Accept and assume the responsibilities associated with being a competent professional and lifelong learner

$\checkmark$ Recognize and practice self-reflection for the purpose of personal professional growth.

\section{Ethical Standards for Nigerian Teachers}

From a philosophical standpoint, ethics are moral beliefs and rules about right and wrong. It is also the study of questions about what is morally right or wrong. The businessdictionary.com defines ethical standards as "Principles that when followed, promote values such as trust, good behavior, fairness, and or kindness." Applying this to the teaching profession, the Trade Union of Education in Finland notes that because teaching is regarded as a profession, it requires its own code of "quality control." It adds that many other professions throughout the generations "have set themselves ethical guidelines that express the attitudes and sense of responsibility that its members are required to show toward their work and clearly stating the common values and principles that they should possess with respect to their profession.'

This notion led regulatory bodies in Nigeria education system to establish standards, rules and code of ethics for teachers.

The Teachers Registration Council of Nigeria (TRCN) was born in 1993 as a professional regulatory body to oversee Nigeria's education professional standards. It acknowledges that the teaching profession in Nigeria now has the features associated with other noble professions. It notes that these features are collectively called 'Professional Standards' which "clearly and precisely define the core values, ideals and conduct that the professional must exhibit." (TRCN 2012, P. 1). Its stated mission includes assuring teacher excellence and professionalism across all levels of the education system, overseeing the effective registration and licensing of teachers, monitoring and supervising teacher education programmes as well as maintaining discipline within the profession (TRCN 2012).

In addition to establishing minimum professional knowledge, skills, membership obligation and guidelines for induction, the TRCN also instituted the following standards on professional values, attitudes

conduct: 
The Teachers Registration Council of Nigeria (TRCN) professional values, attitudes and conduct:

Teachers...

\begin{tabular}{|l|l|}
\hline Honor learners' rights and dignity & Serve as model and mentors to learners \\
\hline Have empathy for learners & Are corruption-free \\
\hline $\begin{array}{l}\text { Maintains confidentiality of learners' personal } \\
\text { information }\end{array}$ & Do not administer corporal punishment on learners \\
\hline Shun sexual and related abuses of power & Inspire self-discipline among learners \\
\hline Are vanguard against examination misconduct & $\begin{array}{l}\text { Check their ideological beliefs in dealing with } \\
\text { learners }\end{array}$ \\
\hline $\begin{array}{l}\text { Uphold learners human right and discourage any } \\
\text { form of discrimination }\end{array}$ & Do not plagiarize \\
\hline Promote democratic decision-making & $\begin{array}{l}\text { Control personal bias and apply objectivity in } \\
\text { discharge of their professional duties }\end{array}$ \\
\hline $\begin{array}{l}\text { Contribute to academic development through } \\
\text { teaching, research and community service }\end{array}$ & $\begin{array}{l}\text { Treat parents and guardians with respect and } \\
\text { courtesy }\end{array}$ \\
\hline Stick to their areas of professional competence & Project exemplary character in society \\
\hline
\end{tabular}

The above list of expectations outlined by the TRCN is an indication of the effort made by the National Assembly of the Federal Republic of Nigeria to regulate and standardize the quality of the teaching profession in Nigeria.

Earlier, in 1969, the Nigerian Union of Teachers (NUT) had formulated professional code of ethics for Nigerian teaching profession. While the main purpose for the NUT was to regulate the behaviour of teachers, the Ontario College of Teachers, a world class teacher education institution states that the purpose for ethical standards for the teaching profession is as follows:

$\checkmark$ to inspire members to reflect and uphold the honour and dignity of the teaching profession

$\checkmark \quad$ to identify the ethical responsibilities and commitments in the teaching profession

$\checkmark \quad$ to guide ethical decisions and actions in the teaching profession

$\checkmark$ to promote public trust and confidence in the teaching profession
(Ontario College of Teachers, 2007. http://www.oct.ca/public/professional-

standards/ethical-standards)

In his review of ethical standards for Nigerian Teachers, Professor Durosaroof the Faculty of Education, university of Ilorin, Nigeria notes that ethics have to do with moral uprightness in dealing with others(Durosaro, 2015). When applied to a profession, it refers to moral principles or rules of conduct or social control mechanism that governs the actions of members of an occupation. In essence, professional code of ethics stipulates rules and regulations which are intended to guide and regulate the conduct of the members of the profession (Ingvarson, 1998).

While the focus here is Nigeria's code of ethics, it is further enlightening to be aware of standards observed by teachers in other parts of the world. Aglazor \& Obi (2016) joins the professional bodies Nigerian ethical standards and Ontario Public Professional standards in the chart below to highlight some standards. 


\begin{abstract}
Nigeria Union of Teacher's Code of Professional Ethics
Commitment to the student: The primary obligation of the teaching profession in Nigeria is to guide children, youths and adults in the pursuit of knowledge and skill to develop healthy attitudes and enable them live in harmony with all other Nigerians, and to become happy, useful and responsible citizens. The ultimate strength of the nation lies in the social responsibility, economic competence and moral strength of individuals.
\end{abstract}

Commitment to parents. We members of the teaching profession share with parents the task of shaping each student's behaviour towards socially acceptable ends. We share with all other citizens' responsibility of the development of sound public policy. We are accountable for participating in development of sound educational programmes and policies and of interpreting them to the public.

Commitment to the community. Teaching profession in Nigeria occupies a position of public trust involving not only the individual teacher's personal conduct, but also the interaction of the school and community. Education is most effective when these many relationships operate in a friendly cooperative and constructive manner.

Commitment to the employer. The members of the teaching profession in Nigeria are inescapably involved in employer-employee relationship. For the purpose of fulfilling our obligation to our students the State of our nation, employ-employee relationship should be so regulated that there shall be mutual respect, understanding and good faith.

Commitment to the profession. The teaching profession is a unique occupation and we believe that the quality of the services of the teaching profession in Nigeria directly influences the future of the nation and its citizens. We strive to give our best to the nation by making the teaching profession attractive so as to encourage persons worthy of the trust to take up teaching as a career.
Canada's Ethical Standards for the Teaching Profession

\section{Care}

The ethical standard of Care includes compassion, acceptance, interest and insight for developing students' potential. Members express their commitment to students' well-being and learning through positive influence, professional judgment and empathy in practice.

\section{Respect}

Intrinsic to the ethical standard of Respect are trust and fair-mindedness. Members honour human dignity, emotional wellness and cognitive development. In their professional practice, they model respect for spiritual and cultural values, social justice, confidentiality, freedom, democracy and the environment.

\section{Trust}

The ethical standard of Trust embodies fairness, openness and honesty. Members' professional relationships with students, colleagues, parents, guardians and the public are based on trust.

\section{Integrity}

Honesty, reliability and moral action are embodied in the ethical standard of Integrity. Continual reflection assists members in exercising integrity in their professional commitments and responsibilities.

\section{The role of teaching practice in teacher education}

There is overwhelming consensus that teaching practice is central to teacher education programmes everywhere in the world (Kasanda, 1995; Ngidi \& Sibaya, 2003:18; Marais \& Meier, 2004:220; Perry, 2004:2). Different institutions and teacher education programmes design or adopt teaching practice policies that are informed by the institution's mission and vision. This mission must be anchored on the belief that aspiring teachers need to clearly understand the responsibilities they are about to undertake. Additionally, aspiring teachers need to be adequately prepared for the classroom by providing enough hands-on practice during teaching practice field experience. Menter (1989:460) reiterates the notion of teaching 
practice as an experiential practice by highlighting literature associated with the apprenticeship model to the concept of field/school experience. Similarly, Lave \& Wenger (1991) point out that regardless of how it may be envisaged, the notion of teaching practice is entrenched in experience-based learning initiated by Dewey (1938), Vygotsky's (1978) social cognitive theory, and founded on the premise of situated learning.

This preparation takes many dimensions in scope and in content. During the one semester field experience, student teachers are expected to observe, learn and participate in all teaching, learning and general schooling activities. Teaching practice provides opportunities for and enables aspiring teachers to:

1. Get to know the school community which includes mentor teacher, school administrators, students, classroom and school routines.

2. Gradually begin taking over some daily classroom and school responsibilities (e.g., morning business, supervising students at recess, taking students to and from lunch and other classes).

3. Work with individuals and small groups, and whole class as assigned by mentor teacher.

4. Develop a communication plan with mentor and field supervisor (e.g., calls, emails, logs, journals).

5. Learn to develop a semester teaching plan (co-teaching and solo) with mentor teacher and supervisor.

6. Attend staff and other school related meetings (e.g., parent conferences, IEP meetings).

7. Begin to take over more daily responsibilities and teach whole class lessons.

8. Plan and co-teach with mentor teacher as scheduled.

9. Plan and solo teach for a designated period of time each day.

10. Develop and present lesson plans to mentor teacher in advance for guidance.

11. Take complete responsibility for classroom.

12. Schedule mid-semester conference with mentor teacher for evaluation purpose.

13. Plan and prepare for supervisor visit based on feedback from mentor teacher.

14. Undergo supervision by university supervisor(s).
15. Schedule end-of-semester conference with mentor teacher and field supervisor.

16. Reflect on overall field experience and develop ongoing professional growth plan.

17. Complete and sign end-of-semester evaluation forms.

\section{CONCLUSION}

It is noteworthy that while their Canadian colleagues emphasized character traits in their professional ethical standards, Nigeria standards focused on duty and relationships. It is also important to note that one cannot dismiss the role of culture in thought processes that gives birth to these values. For global relevance, it is recommended that both standards be practiced.

\section{REFERENCES}

Aglazor, G., 2011. Global exposure: Preservice teachers' perspective on the role of study abroad. Paper presented at Research Seminar Series by Career and Technical Education, Department of Curriculum and Instruction, College of Education, Purdue University, March 25 ${ }^{\text {th }}, 2011$

Aglazor, G. N and Obi, F. B., 2016. Teaching practice handbook for programmers, students and supervisors. University of Calabar Press, Calabar, Nigeria.

Dewey, J., 1938. Experience and Education. New York: Collier.

Durosaro, D. O., 2015. Code of ethics in the teaching profession, http://distantlibraryn g.blogspot.com.ng/2015/02/nigerianunion-of-teachers-code-of.html

Good Teaching Practice - Flinders University.https://www.flinders.edu.au , ... ) Teaching evaluation gateway.

Kasanda, C. D., 1995. Teaching practice at the University of Namibia: Views from student teachers. Zimbabwe Journal of Educational Research, 7:57-68.

Lave, J and Wenger, E., 1991. Situated learning. New York: Cambridge University. 
Marais, $\mathrm{P}$ and Meier, C., 2004. Hear our voices: student teacher's experience during practical teaching. Africa Education Review, 1:220-233.

Menter, I., 1989. Teaching Stasis: Racism, sexism and school experience in initial teacher education. British Journal of Sociology of Education, 10:459-473.

Ngidi, D. P and Sibaya, P. T., 2003. Student teacher anxieties related to practice teaching. South African Journal of Education, 23:18-22.

Perry, R., 2004. Teaching practice for early childhood. A guide for students. Available at http://www.Routledge.comcatalogues./ 0418114838.pdf. Accessed 18 July 2007

Saphier, J., Haley-Speca, M. A and Gower, R., 2008. The skillful teacher: Building your teaching skills (6 Ed.). Acton, MA: Research for better teaching.

The Teachers Registration Council of Nigeria (TRCN)., 2012. Professional Standards for Nigerian Teachers. Federal Republic of Nigeria; Abuja Nigeria

Vygotsky, L., 1978. Mind in Society: The development of higher psychological processes. Cambridge: Harvard University Press.

\section{Other sources consulted}

Teaching practice (n.d.). Collins English Dictionary - Complete \& Unabridged 10th Edition. Retrieved April 19, 2017 from Dictionary.com website http://www.dictionary.com/browse/teachi ng-practice

Cohen, D. K., Raudenbush, S. W and Ball, D. L., 2002. Resources, instruction, and research. In F. Mosteller and R. Boruch (Eds.), Evidence matters: Randomized trials in education research (pp. 80-119). Washington, DC: Brookings Institution Press.

Orlando, M., 2013. Nine Characteristics of a Great Teacher. Faculty Focus. http://www.facultyfocus.com/articles/philo sophy-of-teaching/
Federal Ministry of Education., 1987. Code of Conduct and guidelines for the teaching staff.

Kagan, S and Kagan, M., 2009. Kagan Cooperative Learning. San Clemente, CA: Kagan Publishing. www.KaganOnline.com.

National Center for Manpower Development (NCMD). Course manual for training and development exercise for administrators of schools. Tobaino DC Press Ltd, Lagos.

Robson, G. D., 1991. Continuous process improvement: Simplifying work flow systems. Simon and Schuster, NY.

C. A. R. E.: Strategies for closing the achievement gaps training manual Association for Supervision and Curriculum Development (n.d.). Student style traits: Auditory, Visual, Kinesthetic

Slavin, Robert E., 1991. Student Team Learning: A Practical Guide to Cooperative Learning. National Education Association. Washington D.C.: 1991.

The Teachers Registration Council of Nigeria (TRCN)., 2010. The Teachers Registration Council of Nigeria: Mandatory continuing professional development programme. Mbawa Communication Press Ltd.; Abuja Nigeria.

The Teachers Registration Council of Nigeria (TRCN)., 2012). Professional Standards for Nigerian Teachers. Federal Republic of Nigeria; Abuja Nigeria.

Center for Educational Development (n.d.). Training manual for the national retraining exercise for primary and secondary school teachers in Nigeria. GH Plus Press; Abuja Nigeria.

Verhagen, P., 2006. Connectivism: A new learning theory? elearning, Retrieved November 4, 2008, fromhttp://www.surfspace.nl/nl/Redactieo mgeving/Publicaties/Documents/Connect ivism\%20a\%20new\%20theory.pdf 
Davis, C., Edmunds, E and Kelly-Bateman, V.,

2008. Connectivism. In M. Orey (Ed.), Emerging perspectives on learning, teaching, and technology. Retrieved from http://projects.coe.uga.edu/epltt/index.ph p?title=Connectivism

Handbook on the Management of Teaching Practice in NCE awarding Institutions. http://www.ncceonline.edu.ng/NCCEDigitization/base.html 